\title{
LEGAL INSTRUMENTALISM TO LAW NUMBER 6 YEAR 2014 ON VILLAGES IN WELFARE STATE PARADIGM
}

\author{
Dila Eka Juli Prasetya and Isharyanto \\ Law Faculty of Sebelas Maret Surakarta University \\ E-mail: dila.prasetya@gmail.com
}

\begin{abstract}
This work deliberates legal instrumentalism to gain non legal interest. It is commonly known that be-sides normative framework, a law also integrates non legal issues and other interests. Law in macro level is aimed to ideally integrate sub-systems such as economics, politics, and so on. The existence of Act of Village Number 6 of 2014 which is able to facilitate the idealized non legal achievements needs to be confirmed. The welfare state paradigm is used as a benchmark for tracking review of norms as well testing consequences of legal substance. It reveals that provisions Act of Village Num-ber 6 of 2014 achieves its idealized goals indicated by village welfare in terms of authority optimiz-ation of authority for the achievement of welfare state at village level.
\end{abstract}

Keyword: legal instrumentalism, welfare state, village

\begin{abstract}
Abstrak
Tulisan ini membahas instrumentalisme hukum dalam rangka mencapai tujuan-tujuan nonlegal. Lazim dipahami bahwa selain memiliki kerangka normatif, sebuah undang-undang juga mengintegrasikan isu-isu dan kepentingan-kepentingan nonlegal di sekitarnya. Hukum dalam konteks makro diidealkan untuk mengintegrasikan sub-sub sistem lain seperti ekonomi, politik, dan sebagainya. Hendak dikonfirmasi apakah keberadaan Undang-Undang Nomor 6 Tahun 2014 tentang Desa tersebut mampu memfasilitasi capaian-capaian nonlegal yang diidealkan. Paradigma welfare state digunakan sebagai patokan untuk pelacakan norma selaligus pengujian konsekuensi terhadap substansi hukum di dalamnya. Dari pelacakan tersebut ternyata ketentuan Undang-Undang Nomor 6 Tahun 2014 tentang Desa mampu mencapai tujuan yang diidealkan yaitu tercapainya kesejahteraan bagi seluruh masyarakat Desa melalui optimalisasi kewenangan yang dimiliki desa dalam kerangka pencapaian welfare state dengan pendekatan tingkat desa.
\end{abstract}

Kata kunci: instrumentalisme hukum, welfare state, desa

\section{Introduction}

Long before a modern state was established, village was: firts, a social entity that possesses identity and native culture; second, a democratic government; ${ }^{1}$ and third, had autonomy ${ }^{2}$ to govern the people. ${ }^{3}$ However, fluctuation of political, economic and socio-cultural

M. Iwan Satriawan, "Politik Hukum Pemerintahan Desa di Indonesia", Jurnal Ilmu Hukum, Vol. 7 No. 2, May-August 2013, p. 149.

2 Andress Deny Bakarbessy, "The Position of the Village in the Terms of the Constitutional Construction of the Unitary State of the Republic of Indonesia in the Implementation of the Regional Autonomy", International Journal of Advanced Research, Vol. 2 Issue. 2, 2014, p. 1226.

3 Siti Nuraini, "Hubungan Kekuasaan Elit Pemerintahan Desa”, Jurnal Kybernan, Vol. 1 No. 1, March 2010, p. 2. conditions occurred. The old order regime which initially granted village autonomy revoked the Guided Democracy era. The situation turned back because the village was granted autonomy again through Law Number 19 Year 1965 on Desa Praja. However, it has not implemented and the law has been revoked.

In the New Order era, Law Number 5 Year 1979 on Village Government was established to create village status conformity and village autonomy was revoked, as a result, authority was centralized ${ }^{4}$ to the central government. ${ }^{5}$ This

\footnotetext{
Nadirsyah Hosen, “Indonesian Political Laws in Habibie Era: Between Political Struggle and Law Reform," Nordic Journal of International Law, Vol. 72 No. 4, 2003, p. 490.
} 
continued until the stipulation of Law Number 22 Year 1999 on Regional Government until it was replaced by Law 32 Year 2004 on Regional Government by which Village management was governed.

The ultimate effort to restore authority previously owned by Village was achieved by the ratification of Law No. 6 of 2014 on the Village. This law returned Village authority which was derived from right of origin, local authority of the village scale, and the implementation of the task of assistance. This authority is projected in various fields, namely the implementation of village governance, the implementation of village development, village society development, and the empowerment of rural societies. ${ }^{6}$

The amount of village authority and support of budget resources was received by the village as embodied in Article 72 paragraph (1) of Law Number 6 Year 2014 on the Village. In this context, village has a very strategic position in the development of the Republic of Indonesia. ${ }^{7}$ In addition, Research and Community Service of Bogor Agricultural University reveals that $63.41 \%$ of the Indonesian population live in the village. ${ }^{8}$ Of this number, based on the Regulation of the Minister of Home Affairs Number 56 Year 2015 on Code and Data of Government Administration Area, it spreads over 74,754 villages.

By looking at village positions and opportunities described earlier, the village must take a role and contribute positively to the realization of welfare state through village-level development approaches ${ }^{9}$ since morphology of the city is strongly influenced by the development

Simon Butt, "Regional Autonomy and Legal Disorder: The Proliferation of Local Laws in Indonesia", Sidney Law Review, Vol. 32, 2010, p. 147.

6 Muhammad Ismail, Et.Al., "Sistem Akuntansi PengeloIaan Dana Desa", Jurnal Ekonomi dan Bisnis, Vol. XIX No. 2, August 2016, p. 324.

7 Simon Butt dan Tim Lindsey, "Economic Reform When the Constitution Matters: Indonesia's Constitutional Court and Article 33", Bulletin of Indonesian Economic Studies, Vol. 44 No. 2, 2008, p. 239.

8 Aida Vitayala Hubeis, Et. Al, 2011, Menuju Desa 2030, Yogyakarta: Percetakan Pohon Cahaya, p. 9.

9 Amy Freedman dan Robert Tiburzi, "Progress and Caution: Indonesia's Democracy", Asian Affairs: An American Review, Vol. 39 No. 3, 2008, p. 136 of the village. ${ }^{10}$ In regards to this, the authors are interested in studying the legal instrumentalism of the existence of Law Number 6 Year 2014 on the Village related to the ability to encourage the realization of welfare state paradigm.

\section{Discussion}

Within the state of Welfare State, legal instrumentalism expands. Its condition is described by Bruce Pardy as follows: ${ }^{11}$

Courts frequently rely on policy grounds to justify idiosyncratic results in particular cases. Governments develop policies and programs designed to address a multitude of specific social issues. Legislatures grant administrative agencies broad mandates with minimal oversight, and officials act with their own initiative to craft solutions to what they perceive as pressing society needs. Everywhere state actors take it upon themselves to pursue the ends they deem appropriate.

Legal instrumentalism can be done through law, court, or both. Instrumentalism through law includes 2 (two) types. According to Bruce Pardy, "They can consist of either specific rules that apply to particular facts or parties, or vague rules that provide wide discretion to fashion unique solutions to particular social problems."12 However, legal instrumentalism can take place naturally that is "the first because the rule itself is designed to achieve a specific purpose and the second because the statute creates a regime within which officials have the discretion to determine specific outcomes in specific situations." 13 The making of the law according to David Trubeck is a "purposive human action" which is never autonomous and sterile, loaded with group interests protected in the law.

10 Kasyful Mahalli, "Negara Kesejahteraan dalam Konteks Pembangunan Wilayah”, Jurnal Ekonom, Vol. 18 No. 1, 2015, p. 41.

11 Bruce Pardy, "The Hand Is Invisble, Nature Know Best, and Justice is Blind: Markets, Ecosystems, Legal Instrumentalism, and The Natural Law of System", Tulsa Law Review, Vol. 44, 2008, p. 68.

12 Ibid.

13 Ibid. 
Meanwhile, the court is considered a "professional bureaucracy." According to Mitnzburg, A professional bureaucracy is an organization that hires people who have been through a process of intensive training to turn them into 'specialists. ${ }^{14}$ To determine the character of its specialty: the complex work of the operating professionals cannot easily be formalized, or its outputs standardized by action planning and performance control systems the complex work of the operating professionals cannot easily be formalized, or its outputs standardized by action planning and performance control systems. ${ }^{15}$

Therefore, it is very difficult to actually judge court performance solely in terms of the judges existence. ${ }^{16}$ It is also an independent judge in taking the decision and in the context of his organization, the judges work within the framework of legal certainty, even though the implementation of the framework requires experience to produce an interpretation.

It should be noted that interpretation is required because traditionally, judges are foremost supposed to be loyal to the law. ${ }^{17}$ Practically, the judges for constitutional or administrative cases often have discretion. ${ }^{18}$ Fundamentally, judges in the liberal democratic tradition increasingly forced to fill the gap left by authorities who should legitimately occupy it (i.e. the legislative and the executive branch) with considerable psychological insecurity due to the loss of identifying guidelines. ${ }^{19}$ It is needed because Both the legislative and the executive branch are often incapable to resolve social disputes, the task of producing the necessary law shifting to the judiciary as a result, or what so-called la judiciarisation du droit. ${ }^{20}$ As a result of the $17^{\text {th }}$ World Congress of the Interna-

14 H. Mintzberg, "Structure in 5's: A synthesis of the Research on Organization Design", Management Science, Vol. 26, 2008, p. 333.

15 Ibid., p. 334.

16 Ibid.

17 Bart Nelissen, “Judicial Loyalty Through Dissent or Why The Timing is Perfect for Belgium to Embrace Separate Opinion", Electronic Journal of Comparative Law, Vol.

18 lbid.

19 Ibid.

20 Ibid., p. 7. tional Academy of Comparative Law at Utrecht University (16-22 July 2006) ago, legal instrumentalism became one of the ways in which law can be developed into more and more refined notions, interconnections and codifications coupled with increasingly sophisticated ways of interpretation. ${ }^{21}$

At the ideal level, the instrumentalization of law is considered contradictory to the Rule of Law for this meaning a system of governance based upon generally applicable, abstract rules and limited state discretion, in which the government is subject to the same law as individual citizens. ${ }^{22}$ In the welfare state, to achieve social goals, the state is required to be present in all aspects of social life. ${ }^{23}$ Thus, none of the aspects of people's lives is separated from government intervention. In this context the Village must contribute and take a strategic role to realize the welfare state based on the authority. ${ }^{24}$ Law Number 6 Year 2014 on Villages becomes a starting point for the transformation or village renewal. The built spirit is to provide recognition of village existence as a pillar of nation building, strengthen authority in resource management, and encourage democratic village governance. ${ }^{25}$ By this understanding, the Village is able to create prosperity and be the answer to the problems experienced by local societies. ${ }^{26}$

The optimization of village role in supporting the realization of welfare state in the Unitary State of the Republic of Indonesia is

21 Bas de Gaay Fortman, “A Comparative Exploration into Human Rights as a Moral-Political Force in Judicial Law Development", Utrecht Law Review, Vol. 2 No. 2, 2006, p. 22.

22 Robert B. Keiter, "Beyond the Boundary Line: Constructing a Law of Ecosystem Management", University of Colorado Law Review, Vol. 65, 2004, p. 293.

23 Umbu Lily Pekuwali, "Eksistensi Perda dalam Mewujudkan Kesejahteraan Masyarakat", Jurnal Yustisia, Edisi 79, January-April 2010, p. 105.

24 Catherine Boone, "Decentralization as Political Strategy in West Africa," Comparative Political Studies, Vol. 36 No. 4, May 2003, p. 358

25 Sharma Chanchal. "Decentralization Dilemma: Measuring The Degree And Evaluating The Outcomes", The Indian Journal of Political Science, Vol. 67 No.1, 2006, p. 50

26 Indah Dwi Qurbani, “Menakar Peluang dan Tatangan terhadap Implementasi Undang-Undang Nomor 6 Tahun 2014 tentang Desa," Jurnal Transisi, $9^{\text {th }}$ edition, 2014, p. 66. 
based on several considerations, namely: first, the village is the place where the people who want to build and prospered live; Second, Villages are rich and diverse aspects of local wisdom; third, village-oriented is necessarily implemented in realizing development goals and objectives; and fourth, villages are the center of activities and activities of all elements and components of society in governance, development and public services. ${ }^{27}$

Having found the village role optimization in supporting the welfare state, the next is an evaluation of the development. The development pattern so far is ineffectively materialized for people welfare ${ }^{28}$ due to weak, less clear, and less focused village intentions and strategies to solve problems. ${ }^{29}$ Motivation and orientation tend to accommodate the elite (leader)..$^{30}$ As a result, too many policies are far from people interest. Besides, low social involvement in development ${ }^{31}$, the unidentified basic needs of the society and the dominance of government and/or local government intervention on the village. ${ }^{32}$ As a result, a development gap occurs $^{33}$ which causes high rates of poverty and unemployment far from the welfare state's ideals.

In this regards, the village optimization role to realize welfare state can be done through the following mechanisms. First, the effort to realize the openness of the village society. Village can be the starting point of national development that is not only about physical development but also the development of

27 Yansen TP, 2014, Revolusi dari Desa: Saatnya dalam Pembangunan Percaya Sepenuhnya kepada Rakyat, Jakarta: Elex Media Komputindo, p. 46

28 Benjamin Olken, "Monitoring Corruption: Evidence from a Field Experiment in Indonesia", Journal of Political Economy, Vol. 115 No.2, 2007, p. 218

29 Ari Kuncoro, "Bribery and Time Wasted in Indonesia: A Test of the Efficient Grease Hypothesis", Economics and Finance in Indonesia, Vol. 52 No.1, 2007, p. 32

30 Stein Kristiansen, Et.Al., "Public Sector Reforms and Financial Transparency: Experiences from Indonesian Districts", Contemporary Southeast Asia, Vol. 31 No. 1, 2008, p. 66

31 George Guess, "Comparative Decentralization Lessons from Pakistan, Indonesia and the Philippines", Public Administration Review, Vol. 65 No. 2, 2007, p. 217.

32 Ibid., p. 48.

33 Yuki Fukuoka, "Politics, Business and the State in PostSuharto Indonesia", Contemporary Southeast Asia, Vol. 34 No. 1, 2012, p. 87. the whole village people. The openness and participation of the village is the main requirement, ${ }^{34}$ because through the openness, new ideas and paradigms will penetrate. ${ }^{35}$ Second, society trust. Trust to the society is a basic capital and a leverage factor in building people's confidence to play a role in development. ${ }^{36}$

Third, the optimization of mandate to the village government. Delegation of power to Village will be a strength for the village government in managing its potential. The results are the creation of village self-reliance, improving the welfare of the village society, as well as the increase of village's original income (PAD) $)^{37}$ which will be realized in the form of welfare programs from the village either social assistance, health insurance, or educational assistance. ${ }^{38}$ Fourth, providing training for village officers. ${ }^{39}$ Coaching and training are useful for improving performance capacity. ${ }^{40}$

Fifth, mentoring village government and society. Through this effort the society and government are expected to understand the main functions and tasks, and comprehend well the various aspects of its implementation. ${ }^{41}$

The optimization of village role to realize welfare can be done through the village autonomy guaranteed by Law Number 6 Year 2014 on the Village, through the existence of principle of recognition, namely the recognition of the

34 Sarah Rum Handayani Pinta, "Empowerment of Female Batik Worker on the Development of Batik Industry in Sragen: Case Study at Wisata Kliwonan Village Subdistrict Masaran", International Journal of Humanities and Social Science, Vol. 3 No. 11, June 2013, p. 122.

35 Bambang Sjahrir, Krisztina Kis-Katos and Günther Schulze, "Administrative Overspending in Indonesian Districts: The Role of Local Politics," World Development, Vol. 59, 2014, p. 178.

36 Yansen TP, Op.Cit. p. 73.

37 Paluku Kazimoto, "Analysis of Village Financial Management Challenges in Arumeru District in Tanzania", International Journal of Reasearch in Social Sciences, Vol. 3 No. 2, 2013, p. 37.

38 Suci Indah Hanifah dan Sugeng Praptoyo, "Akuntabilitas dan Transparansi Pertanggungjawaban Anggaran Pendapatan Belanja Desa (Apbdes)", Jurnal Ilmu \& Riset Akuntansi, Vol. 4 No. 8, 2015, p. 3.

39 Ibid., p. 75.

40 Linda Muchacha Paramitha, Tjahjanulin Domai, dan Suwondo, "Kinerja Aparat Pemerintah Desa dalam Rangka Otonomi Desa (Studi di Desa Gulun, Kecamatan Maospati, Kabupaten Magetan), Jurnal Administrasi Publik, Vol. 1 No. 4, 2013, p. 93.

41 Ibid., p. 76. 
right of origin. Village autonomy is a genuine, absolute, and complete autonomy and is not a gift from the government. Instead, the government is obliged to respect the original autonomy possessed by the village. The integration between flexibility and capacity will result in the independence of the village, through the management of government, decision-making, and management of local resources in accordance with the local societies preferences.

Having found a way to contribute positively in realizing the welfare state in the Unitary State of the Republic of Indonesia (NKRI), the village will be able to realize it directly through the policies issued and agreed by all components in the village. For example, the management of village water resources that can be optimized through the establishment of BUMDes as existed in Ponggok Village, Polanharjo Sub-district, Klaten District with the existence BUMDES of Tirta Mandiri. BUMDES Tirta Mandiri currently has controlled at least and subsidiaries, ie: PT Umbul Ponggok which manages the tourist destinations of Umbul Ponggok, PT. Sumber Panguripan which runs the village shop, PT. Ponggok Ciblon which manages the tourist destinations of Ponggok Ciblon area, PT. Banyu Panguripan who manages the Ponggok Village Building, PT. Artha Tirta Ponggok which manages the people's credit, PT. Bangun Tirta Jaya who manages the construction services business, PT. Air Ponggok which manages clean water and bottled water, and PT. Mina Tirta Mulia which manages ponds and fisheries. These few subsidiaries can generate a village's original income (PADes) of 5 (five billion) per year. The income is linked by Ponggok Village Government with poverty alleviation program and for family whose members hold student status will get subsidy of 300 (three hundred) thousand rupiah per month. In addition, the shares of BUMDes are owned by Ponggok Village residents and surrounding areas. ${ }^{42}$

42 Humas Jateng, June $16^{\text {th }}$ 2016, "BUMDes Ponggok Bantu Entaskan Kemiskinan", available on: http://www. jatengprov.go.id/id/berita-utama/bumdes-umbul-pong gok-bantu-entaskan-kemiskinan, accessed on October $16^{\text {th }}, 2016$.
More importantly, it is to realize economic reliance at the village level as well as control over the resources owned as a form of implementation Article 33 paragraph (3) of the 1945 Constitution of the Republic of Indonesia which explains that the Earth and water and natural resources contained therein are controlled by the state and used for the people prosperity. In this case, water resources is one efforts to realize welfare state by village level approach rather than managed by external investors who would certainly be more profitable for investors rather than the village society. ${ }^{43}$

\section{Conclusion}

The legal instrumentalism of the existence of Law Number 6 Year 2014 on the Village is able to encourage the realization of the welfare state paradigm through the openness of the village society, social trust, the optimization of mandate to the village government, coaching and training the village apparatus, as well as the assistance of the government and the village society. This is supported by the existence of one of the principles adopted by Law Number 6 Year 2014 on the Village, which is the principle of recognition which provides assurance of authority based on the right of origin to be optimized towards a welfare state achievement with village approach in accordance with the village potentials.

\section{Suggestion}

In order to achieve non-aligned goals that ideally the realization of the welfare of the state with the village-level approach, it should be supported by positive commitment among stakeholders, indigenous villages, indigenous village apparatus, supravillage government, and those closely linked in efforts to achieve village prosperity and welfare.
43 Isharyanto and Dila Eka Juli Prasetya, 2016, Hukum Pemerintahan Desa: Perspektif, Konseptualisasi, dan Konteks Yuridis, Yogyakarta: CV Absolute Media, p. 316. 


\section{References}

A Hubeis, ida Vitayala. Et.Al. 2011. Menuju Desa 2030. Yogyakarta: Percetakan Pohon Cahaya;

Bakarbessy, Andress Deny. "The Position of the Village in The Terms of the Constitutional Construction of the Unitary State of the Republic of Indonesia in The Implementation of the Regional Autonomy". International Journal of Advanced Research. Vol. 2 Issue. 2. 2014. Pp. 1226-1233;

Boone, Catherine. "Decentralization as Political Strategy in West Africa". Comparative Political Studies. Vol. 36 No. 4. Mei 2003. Pp. 355-380. DOI: 10.1177/001041400325 1173;

Butt, Simon and Tim Lindsey. "Economic Reform When the Constitution Matters: Indonesia's Constitutional Court and Article 33". Bulletin of Indonesian Economic Studies. Vol. 44 No. 2. 2008. p. 239-262;

Butt, Simon. "Regional Autonomy and Legal Disorder: The Proliferation of Local Laws in Indonesia", Sidney Law Review, Vol. 32, 2010, Pp. 1-21;

Chanchal, Sharma. "Decentralization Dilemma: Measuring The Degree And Evaluating The Outcomes". The Indian Journal of Political Science. Vol. 67 No.1. 2006. Pp. 4964;

Fortman, Bas de Gaay. "A Comparative Exploration into Human Rights as a Moral-Political Force in Judicial Law Development". Utrecht Law Review. Vol. 2. No. 2. 2006. Pp. 22-43. DOI: 10.18352/ulr.24;

Freedman, Amy and Tiburzi, Rober. "Progress and Caution: Indonesia's Democracy". Asian Affairs: An American Review. Vol. 39 No. 3. 2008. Pp. 131-156. DOI: 10.1080/00927678.2012.704832;

Fukuoka, Yukl. "Politics, Business and the State in Post-Suharto Indonesia". Contemporary Southeast Asia. Vol. 34 No. 1. 2012. Pp. 80-100;

Guess, George. “Comparative Decentralization Lessons from Pakistan, Indonesia and the Philippines". Public Administration Review. Vol. 65 No. 2. 2007. Pp. 217-230. DOI: 10.1111/j.1540-6210.2005.00446.x;

Hanifah, Suci Indah and Praptoyo, Sugeng. "Akuntabilitas Dan Transparansi Pertanggungjawaban Anggaran Pendapatan Belanja Desa (APBDes)". Jurnal Ilmu \& Riset Akuntansi. Vol. 4 No. 8. 2015. Pp. 1-15;
Hosen, Nadirsyah. "Indonesian Political Laws in Habibie Era: Between Political Struggle and Law Reform," Nordic Journal of International Law, Vol. 72 No. 4, 2003. Pp. 483-581;

Humas Jateng. 16 Juni 2016. "BUMDes Ponggok Bantu Entaskan Kemiskinan”. Available on: http://www.jatengprov.go.id/id/ berita-utama/bumdes-umbul-ponggokbantu-entaskan-kemiskinan, Accesed on October $16^{\text {th }} 2016$;

Isharyanto and Dila Eka Juli Prasetya. 2016. Hukum Pemerintahan Desa: Perspektif, Konseptualisasi, dan Konteks Yuridis. Yogyakarta: CV Absolute Media;

Ismail, Muhammad. Et.Al. "Sistem Akuntansi Pengelolaan Dana Desa”. Jurnal Ekonomi dan Bisnis. Vol. 19 No. 2. August 2016. Pp. 323-340;

Kazimoto, Paluku. “Analysis of Village Financial Management Challenges in Arumeru District in Tanzania". International Journal of Reasearch in Social Sciences. Vol. 3 No. 2. October 2013. Pp. 33-39;

Keiter, Robert B. "Beyond the Boundary Line: Constructing a Law of Ecosystem Management". University of Colorado Law Review. Vol. 65. 2004. Pp. 293-233;

Kristiansen, Stein. Et.Al. "Public Sector Reforms and Financial Transparency: Experiences from Indonesian Districts". Contemporary Southeast Asia. Vol. 31 No. 1. 2008. Pp. 64-87;

Kuncoro, Ari. "Bribery and Time Wasted in Indonesia: A Test of the Efficient Grease Hypothesis". Economics and Finance in Indonesia. Vol. 52 No.1. 2007. Pp. 31-53;

Mahalli, Kasyful. "Negara Kesejahteraan dalam Konteks Pembangunan Wilayah”. Jurnal Ekonom. Vol. 18 No. 1. 2015. Pp. 38-48;

Mintzberg, H. "Structure in 5's: A synthesis of the Research on Organization Design", Management Science, Vol. 26 No. 3. 1980. Pp. 322-341. DOI: 10.1287/mnsc.26.3. 322;

Nelissen, Bart. “Judicial Loyalty Through Dissent or Why The Timing is Perfect for Belgium to Embrace Separate Opinion". Electronic Journal of Comparative Law. Vol. 15. No. 1. December 2011. Pp. 1-14;

Nuraini, Siti. “Hubungan Kekuasaan Elit Pemerintahan Desa”. Jurnal Kybernan. Vol. 1 No. 1. March 2010. Pp. 1-13; 
Olken, Benjamin. "Monitoring Corruption: Evidence from a Field Experiment in Indonesia”. Journal of Political Economy. Vol. 115 No. 2. 2007. Pp. 200-248;

Paramitha, Linda Muchacha. Tjahjanulin Domai. and Suwondo. "Kinerja Aparat Pemerintah Desa dalam Rangka Otonomi Desa (Studi di Desa Gulun, Kecamatan Maospati, Kabupaten Magetan)". Jurnal Administrasi Publik. Vol. 1 No. 4. 2013. Pp. 91 100;

Pardy, Bruce. "The Hand Is Invisble, Nature Know Best, and Justice is Blind: Markets, Ecosystems, Legal Instrumentalism, and The Natural Law of System". Tulsa Law Review. Vol. 44. 2009, p. 67-92;

Pekuwali, Umbu Lily. "Eksistensi Perda dalam Mewujudkan Kesejahteraan Masyarakat". Jurnal Yustisia. Edisi 79. Januari-April 2010. p. 105-113;

Pinta, Sarah Rum Handayani. "Empowerment of Female Batik Worker on the Development of Batik Industry in Sragen: Case Study at Wisata Kliwonan Village Subdistrict Masaran". International Journal of Humanities and Social Science. Vol. 3 No. 11. June 2013. Pp. 122-129;

Qurbani, Indah Dwi. “Menakar Peluang dan Tantangan terhadap Implementasi UndangUndang Nomor 6 Tahun 2014 tentang Desa". Jurnal Transisi. Edisi 9. 2014. p. 6678;

Satriawan, M. Iwan. "Politik Hukum Pemerintahan Desa Di Indonesia". Jurnal Ilmu Hukum. Vol. 7 No. 2. May-August 2013. Pp. 149-159. DOI: 10.25041/fiatjustisia.v7 no2.373;

Sjahrir, Bambang. Krisztina Kis-Katos and Günther Schulze. "Administrative Overspending in Indonesian Districts: The Role of Local Politics," World Development, Vol. 59, 2014, p. 178. DOI: 10.1016/j. worlddev.2014.01.008;

TP, Yansen. 2014. Revolusi dari Desa: Saatnya dalam Pembangunan Percaya Sepenuhnya kepada Rakyat. Jakarta: Elex Media Komputindo. 